\title{
CHARACTERIZATION OF SOIL PARAMETERS OF TWO SOILS OF RIO GRANDE DO SUL IN MODELING THE PREDICTION OF TRACTIVE EFFORT
}

\author{
ANTÔNIO L. T. MACHADO ${ }^{1}$, CARLOS R. TREIN ${ }^{2}$
}

\begin{abstract}
The interaction between the soil and tillage tool can be examined using different parameters for the soil and the tool. Among the soil parameters are the shear stress, cohesion, internal friction angle of the soil and the pre-compression stress. The tool parameters are mainly the tool geometry and depth of operation. Regarding to the soils of Rio Grande do Sul there are hardly any studies and evaluations of the parameters that have importance in the use of mathematical models to predict tensile loads. The objective was to obtain parameters related to the soils of Rio Grande do Sul, which are used in soil-tool analysis, more specifically on mathematical models that allow the calculation of tractive effort for symmetric and narrow tools. Two of the main soils of Rio Grande do Sul, an Albaqualf and a Paleudult were studied. Equations that relate the cohesion, internal friction angle of the soil, adhesion, soil-tool friction angle and pre-compression stress as a function of water content in the soil were obtained, leading to important information for use of mathematical models for tractive effort calculation.
\end{abstract}

KEYWORDS: Soil cohesion, soil-tool adhesion, pre-compression stress.

\section{CARACTERIZAÇÃO DOS PARÂMETROS DE SOLOS DO RIO GRANDE DO SUL UTILIZADOS NA MODELAGEM DA PREDIÇÃO DO ESFORÇO DE TRAÇÃO}

RESUMO: A interação que ocorre entre o solo e a ferramenta de preparo pode ser analisada por meio de diferentes parâmetros. Entre os parâmetros do solo, encontram-se a tensão de cisalhamento, a coesão, o ângulo de atrito interno do solo e sua tensão de pré-adensamento. Os parâmetros da ferramenta considerados são principalmente sua geometria e a profundidade de atuação. Com relação aos solos do Rio Grande do Sul, praticamente não existem estudos e avaliações dos parâmetros que apresentam importância na utilização de modelos matemáticos para previsão de esforços de tração. O objetivo do trabalho foi a obtenção de parâmetros relacionados aos solos do Rio Grande do Sul, os quais são utilizados na análise da relação ferramenta-solo, mais especificamente nos modelos matemáticos que permitem o cálculo do esforço de tração de ferramentas simétricas e estreitas. Estudaram-se dois dos principais solos do Rio Grande do Sul: Planossolo e Argissolo Vermelho. Obtiveram-se equações que relacionam a coesão, o ângulo de atrito interno do solo, a adesão, o ângulo de atrito solo-material e a tensão de pré-adensamento em função do teor de água presente no solo, permitindo contar-se com informações importantes para utilização nos modelos matemáticos de cálculo do esforço de tração.

PALAVRAS-CHAVE: coesão do solo, adesão solo-material, tensão de pré-adensamento.

\section{INTRODUCTION}

The study of soil-machine relationship and an attempt to establish mathematical models associated with this relationship are the basis of the dynamics of soil. A better understanding of soil-tool interface can be obtained by correlating the rheological behavior of soil with its dynamic features, and the disruption of the soil will depend on the geometry of the tool, operating speed and soil physical properties (KARMAKAR \& KUSHWAHA, 2006).

\footnotetext{
${ }^{1}$ Dr., Bolsista CNPq-Brasil; Professor Associado III; Universidade Federal de Pelotas, Faculdade de Agronomia Eliseu Maciel; Departamento de Engenharia Rural, Campus Capão do Leão; C.P., 354; CEP 96010-900; Pelotas-RS; fone: 53-3275-7126.

${ }^{2}$ Dr. Professor Associado IV; Universidade Federal do Rio Grande do Sul, Departamento de Solos; Avenida Bento Gonçalves, 7712 , CEP 91540-000; Porto Alegre-RS; fone: 51-3308-6848.

Recebido pelo Conselho Editorial em: 17-11-2011
}

Aprovado pelo Conselho Editorial em: 4-2-2013 
The tractive effort of a tillage tool varies widely depending on different conditions, which relate to the tool and soil condition (MANUWA, 2009; CAMACHO-TAMOYO \& RODRÍGUEZ, 2007).

According to GODWIN \& DOGHERTY (2007), the knowledge of the forces that act on the tools while working, in conjunction with the soil tool interaction mechanisms are important for the design of more effective elements of soil mobilization. The type and degree of soil mobilization are the main factors in the selection of tillage equipment.

Interaction between soil and tool can be analyzed by means of different soil parameters and the tool itself. Among the soil parameters are the shear stress, cohesion, the internal friction angle of the soil and the pre-compression stress. The tool parameters consider the rake angle, the depth and the working speed. Among those relating to soil-interaction tool, it can be relate to the adhesion and the angle of friction between soil and the tool material. Such parameters are used in the development of theories and mathematical models that try to quantify and predict the tractive effort produced by tools. For a better understanding of the relationship between soil-preparation tools, there is a need to know what it is and which factors influence soil shear strength, which is directly related to the actual contact between the soil particles, directly influencing its resistance to deformation. A direct shear test can allow the evaluation of the resistance of a soil sample to shear and, consequently, its internal friction angle and cohesion, important parameters in mathematical models for prediction of stress caused by tillage tools. The study of soil compressibility comes to be of fundamental importance, since it makes it possible to obtain their pre-compression stress, which allows identifying the maximum loading that the soil can withstand without permanent deformation.

LAMANDÉ \& SCHJØNNING (2011a), report that stress transmission in soil is a crucial ingredient of the cause-and-effect chain, and may lead to a plastic or elastic deformation of the soil. In their studies a maximum value of soil strain was caused by $200 \mathrm{kPa}$ tire tractors at a $0.3 \mathrm{~m}$ depth. The reduction of the capacity of soil to support loads after recent mobilization optimizes stress distribution on the interface-tire-ground, not affecting the spread of tensions to deeper layers.

The increase in loads of wheeled machines used in agriculture has increased the magnitude of tensions caused in the soil, in ever increasing depth (LAMANDÉ \& SCHJØNNING, 2011b). The mechanical property used in the prediction of the load-bearing capacity of the soil, to predict the effects of traffic on soil structure, is the pre-compression stress, which varies depending on the water content of the soil (SILVA et al., 2007 and CAVALIERE et al., 2008).

The most used method of obtaining pre-compression stress was developed by Casagrande in 1936; being a graphical method it is prone to imperfections (RÜCKNAGEL et al., 2010). In his study these authors concluded that the method presented an error of $15 \%$, which is tolerable for most applications. For the same condition of soil, the factor that governs the amount of deformation that may occur is the water content. Getting data from soil pre-compression stress in different water levels, it is important to define the situation of use of agricultural machinery in order to not cause pressures in excess of its ability to support, since the transmission of stresses in soil is extremely sensitive to changes in water content (DIAS JÚNIOR \& PIERCE, 1996; MACHADO \& TREIN, 2000; LAMANDÉ \& SCHJØNNING, 2011 c).

Among other parameters that are important for soil characterization and the study of soilpreparation tool are soil texture, porosity, density, density of solids, plasticity index and contraction threshold, which has been widely studied. The aim of this study was to obtain the values of the internal friction angle, cohesion, adhesion, pre-compression stress, soil-tool friction angle and adhesion angle, for both the Albaqualf and Paleudult, thereby allowing stress calculation in different soil water content to be used in mathematical models that allow the calculation of tractive effort of symmetric and narrow tools. 


\section{MATERIAL AND METHODS}

The study was developed in two different soils: Albaqualf and Paleudult. These two soils characterize some of the most frequent soils of Rio Grande do Sul, Brazil.

The Albaqualf is at the experimental field of the agricultural machinery Sector of DERFAEM, located in Pelotas, Rio Grande do Sul, between 31 ${ }^{\circ} 52^{\prime} 00^{\prime \prime}$ South and 52 $21^{\prime} 24^{\prime \prime W e s t: ~ i t ~ i s ~}$ currently called 'Planossolo Hidromórfico'. The area was under natural pasture and had not been tilled for ten years.

The Paleudult soil is at the Experimental Station of the Faculty of Agronomy of UFRGS, in Eldorado do Sul, RS, between $30^{\circ} 05^{\prime} 27^{\prime \prime}$ South and $51^{\circ} 40^{\prime} 18^{\prime \prime}$ West, currently classified as Red typical Distrophic Argisols. The area was covered with pasture of clover and grasses.

For cohesion and the internal friction angle of the soil, undisturbed soil samples were taken at $0.20 \mathrm{~m}$ depth, in rings $0.063 \mathrm{~m}$ internal diameter and $0.025 \mathrm{~m}$ high. Fifteen samples per plot were taken. A set of five soil cores, after saturation, was subjected to a certain level of suction, in Richards' Pressure Chamber, to suction levels of 100; 330 and $15000 \mathrm{kPa}$, characterizing soil in three situations of water content, namely:

a-Between the upper and lower limit of plasticity;

b- Intermediary between the contraction limit and the lower limit of plasticity;

c- Lower than the limit of soil contraction.

In this way it was possible to identify each soil as moist, crumbly and dry. Pre-compression stress was obtained following the recommendations set out in MB-336 (ABNT, 1990), through the use of a brand name Testop oedometer, belonging to the Soils Department of the Faculty of Agronomy of UFRGS.

Soil cores were confined laterally by a ring of steel and top and bottom by porous plates. The vertical load was applied by a rigid distribution device with uniform pressure. Loading stresses were applied in small increments, and the vertical deformation was measured with the aid of a deflectometer.

Each sample was subjected to seven load increments, with the values of $12.5 ; 25 ; 50 ; 100$; 200; 400 and $800 \mathrm{kPa}$. The weights were changed manually, every five minutes, and readings were taken at intervals of 30 ", 1 ', 2 ', 4 ' and 5 '. The five-minute interval was defined previously, and more than $90 \%$ of the sample consolidation occurs in this time interval. With these data, porosity index was plotted against the logarithm of vertical effective stress for each of the soils, in every condition of water content. From these curves and through the process of Pacheco Silva (ABNT, 1990) the pre-compression stress was attained.

In each soil and water content for the various normal stresses was obtained a value for the maximum shear strain. Soil cores were taken to direct shear equipment, Soiltest, model D-350A-4 at the Soils Department of the Faculty of Agronomy of UFRGS. Each set of five samples underwent normal stresses of 8.67; 17.34; 34.69; 69.37 and 138,74kPa, and, in each loading situation, a tenminute time interval for densification was allowed. Graphics correlating the normal stress with maximum shear strain were built, with the internal friction angle and cohesion of soil, in every situation of water content in the soil, on a total of three values for each situation. Later the average for every soil and water content was estimated.

The internal friction angle and the soil-material adhesion were obtained through the collection of soil cores to a depth of $0.20 \mathrm{~m}$, in rings, whose dimensions are the same as those used for the direct shear test, previously described. The samples were in number of fifteen per plot. In the same way as in direct soil shear test, each set of five samples, after saturation, was subjected to the same suction levels described above characterizing the soil in their plastic, crumbly and dry consistency. Soil samples were subjected to the same direct shear equipment. Soil cores were placed at the top 
end of the shear box and at the bottom was installed a core of the same material used in the manufacturing of chisel plough. The soil-material adhesion index and soil-material friction angle were attained. Other soil physical parameters; water content, texture, plasticity index, soil density, density of solids, total porosity, macro and micro porosity of soil were obtained from nine soil cores taken at the depth of $0.20 \mathrm{~m}$, at each site. The procedures for its determination were those recommended as standard in the area of soil physics.

\section{RESULTS AND DISCUSSION}

Soil physical parameters of the soils are in Table1

TABLE 1. Physical parameters for characterization of the studied soils (average values of nine repetitions).

\begin{tabular}{lll}
\hline Parameter & Albaqualf & Paleudult \\
\hline Sand & Texture $\left({\left.\mathrm{kg} . \mathrm{kg}^{-1}\right)}^{-1}\right.$ & \\
Silt & 0.620 & 0.672 \\
Clay & 0.263 & 0.150 \\
\hline & 0.117 & 0.178 \\
\hline Soil density & Density $\left(\mathrm{kg} . \mathrm{m}^{-3}\right)$ & \\
Particle density & 1513 & 1570 \\
\hline & 2695 & 2636 \\
\hline Upper plasticity limit & Atterberg limits $\left(\mathrm{kg}^{-3} \mathrm{~kg}^{-1}\right)$ \\
Lower plasticity limit & 0.217 & 0.226 \\
Plasticity index & 0.181 & 0.139 \\
\hline & 0.036 & 0.087 \\
\hline Macroporosity & Porosity (m3. m-3) & \\
Microporosity & 0.086 & 0.149 \\
Total porosity & 0.353 & 0.268 \\
\hline
\end{tabular}

Observing the texture data and using the diagram of textural classes for particle size classification, both soils can be classified as sandy loam soils. However it turns out that the amount of clay present in the Paleudult is higher that of Albaqualf.

Both, soil density and particle density are very close for the two soils.

Regarding Atterberg limits, both soils have similar values for the upper plasticity Limit (UPL) but, in relation to the lower plasticity limit (LPL) there is a difference, allowing a plasticity index more than twice for the Paleudult, when compared to that found for the Albaqualf. Therefore, there is a lower water holding capacity by Paleudult, compared to the Albaqualf, which has the highest water-holding capacity. Also, through observation of the Atterberg limits, the amount of water necessary to soils to reach the plastic state or to become friable or even completely saturated.

By testing it was found that, for the studied soils, when applying a suction of $100 \mathrm{kPa}$, the remaining amount of water would correspond to the water content of the soil in the plastic phase, because the value obtained was below the upper plasticity limit (UPL) and above the lower 
plasticity limit (LPL). When soils were subjected to a suction of $330 \mathrm{kPa}$, more water was taken from the soil samples allowing soils to attain friability, as the amount of water remaining in the sample was below the LPL. When the samples were subjected to a suction of $15000 \mathrm{kPa}$ soils reached the dry state.

Micro porosity is higher than macro porosity in both soils, and the Paleudult macroporosity and microporosity are lower when compared to Albaqualf. It is also noted that, although the macro and microporosity values are different, the total porosity values are quite close.

The use of charts that correlate the maximum shear stress $(\tau)$ versus normal stress $(\sigma)$, in three soil moisture content, allowed getting a linear equation which enabled the calculation of the internal friction angle $(\phi)$ and cohesion (C) of the both soils.

The values of the internal friction angle and cohesion of soil to the Albaqualf are presented in table 2 .

TABLE 2. Values of moisture $(\theta)$, internal friction angle $(\phi)$ and cohesion(C), for Albaqualf (mean of three repetitions).

\begin{tabular}{lll}
\hline$\theta\left(\mathrm{kg} \cdot \mathrm{kg}^{-1}\right)$ & $\phi\left(^{0}\right)$ & $\mathrm{C}(\mathrm{kPa})$ \\
\hline 0.19 & 32.24 & 21.02 \\
0.14 & 32.31 & 31.36 \\
0.12 & 33.34 & 31.65 \\
0.08 & 35.20 & 31.73 \\
\hline
\end{tabular}

With these results it was possible to establish the relationship between (C) cohesion and the internal friction angle $(\phi)$ as a function of water content.

$$
\begin{aligned}
& C=-1583.5 \theta^{2}+332.41 \theta+15.129 ; r^{2}=0.9808 \\
& \phi=337.94 \theta^{2}-118.88 \theta+42.593 ; r^{2}=0.9808
\end{aligned}
$$

Cohesion features small variation in soil water levels between 0.08 and $0.14 \mathrm{~kg}_{\mathrm{kg}} \mathrm{kg}^{-1}$, which characterizes the dry and crumbly soil state. By the middle of table 2 also shows that cohesion falls sharply when the water content is 0.14 to $0.19 \mathrm{~kg}_{\mathrm{kg}}{ }^{-1}$, which characterizes the value soil in its plastic state. It is evident therefore that the excess water on the soil has a role of lubrication.

Internal friction angle $(\phi)$ shows little variation (around $3^{\circ}$ ), when the soil has water content of 0.19 (maximum) and $0.08 \mathrm{~kg}^{\mathrm{kg}}{ }^{-1}$ (minimum), although it is possible to observe that it has the tendency to decrease as the water content increases.

Through the equations laid down, calculating the cohesion and internal friction angle of Albaqualf, with different moisture is possible, and are regarded as important tools in the study of the models that calculate the tractive effort provided by a tillage tool.

The values of the internal friction angle and soil cohesion of Paleudult are in Table3

TABLE 3. Values of moisture (kg. $\left.\mathrm{kg}^{-1}\right)$, internal friction angle $(\phi)$ and soil cohesion (C), for Paleudult (mean of three repetitions).

\begin{tabular}{lll}
\hline Water content $\left(\mathrm{kg} \cdot \mathrm{kg}^{-1}\right)$ & $\phi\left(^{0}\right)$ & $\mathrm{C}(\mathrm{kPa})$ \\
\hline 0.13 & 33.19 & 26.40 \\
0.11 & 38.63 & 32.19 \\
0.09 & 40.92 & 69.99 \\
0.08 & 41.17 & 72.34 \\
\hline
\end{tabular}


The data regression analysis resulted in the equations that relate the cohesion and the internal friction angle of Paleudult, depending on its water content:

$$
\begin{aligned}
& C=12752 \theta^{2}-3722.9 \theta+293.15 ; r^{2}=0.9261 \\
& \phi=-3661.5 \theta^{2}+610.64 \theta+15.707 ; r^{2}=0.9997
\end{aligned}
$$

By analyzing table 3 it turns out that cohesion increases sharply with decrease of water content of the soil, going so far as to be almost three times higher when this soil goes from a water content of $0.13 \mathrm{~kg} . \mathrm{kg}^{-1}$ to $0.08 \mathrm{~kg} \cdot \mathrm{kg}^{-1}$.

It is also possible to check what occurs in Paleudult regarding the behavior of its internal friction angle. It turns out, comparing the results with those attained with Albaqualf, which, although showing a lower variation of water content, changing this factor was greater in Paleudults. However, the two soils showed the same trend, i.e., the increase of the internal friction angle with the decrease in soil water content.

With the previously established equation, it becomes possible to calculate the internal friction angle and cohesion to the Paleudults, in different situations of water content in the soil. As it happens with Albaqualf, this comes to be an important tool for the study of mathematical models to calculate the tractive effort necessary to pull tillage equipment.

The analysis of Tables 2 and 3 shows that for both soils there is a trend to cohesion increase as the water content in the soil decreases, which had been expected, since the lower the water content in the soil, the stronger is the attraction between soil particles. With respect to the internal friction angle of soil, it turns out, that it increases for both soils as the water content in the soil is reduced, even though the values obtained being slightly different (and higher) for the Red Argisols.

The comments above are in line with those of KARMAKAR \& KUSHWAHA, (2006), MANUWA, (2009) and CAMACHO-\& TAMOYO RODRÍGUEZ, (2007), which correlate the content of water as the most important factor in soil-machine relationship.

SÁNCHEZ-GIRÓN (1996), indicates that the solid and liquid phases of the soil condition its mechanical behavior, and water filling up the pores (to saturation) reduce the contact forces between the particles, reducing shear resistance, by reducing its internal friction.

Through data that correlate the maximum soil shear strain -material $\left(\tau_{\mathrm{a}}\right)$ and the normal stress $(\sigma)$, in three levels of water, it becomes possible to obtain the line equation which allows the calculation of soil friction angle-material $(\delta)$ and soil-material adhesion $(\mathrm{Ca})$ of Albaqualf and Paleudult, in different conditions of soil water content.

The soil friction angle values-soil adhesion and material-material, for the Albaqualf are presented in table 4, while those concerning Paleudult, can be found in table 5.

TABLE 4. Values of soil moisture $\left(\mathrm{kg}^{\mathrm{kg}} \mathrm{kg}^{-1}\right)$, soil-material friction angle $(\delta)$ and soil-material adhesion (Ca), for Albaqualf (mean of three repetitions).

\begin{tabular}{lll}
\hline Water content $\left(\mathrm{kg} \cdot \mathrm{kg}^{-1}\right)$ & $\delta\left({ }^{\mathrm{o}}\right)$ & $\mathrm{Ca}(\mathrm{kPa})$ \\
\hline 0.22 & 26.10 & 6.17 \\
0.15 & 30.38 & 3.83 \\
0.13 & 31.35 & 3.53 \\
0.10 & 35.05 & 2.12 \\
\hline
\end{tabular}

With the above information the equations relating to soil friction angle and soil adhesion material to material, were derived as a function of soil water content, as follows:

$$
\mathrm{Ca}=32.521 \theta-0.8679, \mathrm{r}^{2}=0.9863
$$




$$
\delta=-70.983 \theta+41.158, \mathrm{r}^{2}=0.9782
$$

TABLE 5. Values of water content $\left(\mathrm{kg}^{\mathrm{kg}} \mathrm{kg}^{-1}\right)$, soil-material friction angle $(\delta)$ and soil-material adhesion (Ca), for Paleudult (mean of three repetitions).

\begin{tabular}{lll}
\hline Water content $\left(\mathrm{kg}^{\mathrm{kg}}{ }^{-1}\right)$ & $\delta\left({ }^{\mathrm{o}}\right)$ & $\mathrm{Ca}(\mathrm{kPa})$ \\
\hline 0.13 & 30.31 & 6.97 \\
0.11 & 31.79 & 6.34 \\
0.09 & 33.76 & 1.76 \\
0.08 & 34.18 & 1.40 \\
\hline
\end{tabular}

In the same way as for the previous case, from this information it was possible the establishment of equations for the angle of friction between soil and tillage shank material and the adhesion soil to material, for the Paleudult, depending on the water content, as presented below:

$$
\begin{aligned}
& \mathrm{Ca}=1680.5 \theta^{2}+479.4 \theta-26.745, \mathrm{r}^{2}=0.9281 \\
& \delta=-76.085 \theta+40.371, \mathrm{r}^{2}=0.9864
\end{aligned}
$$

It should be noted that soil-material adhesion for both soils decreased while suction increased, that is, as the soil dries out. The drier the soil, the lower the trend in adhering to the tool, because with the reduction of water in the soil adhesion ceases to exist and only friction between the tool material and the soil are acting.

Also the angle of soil-tool friction, presents similar behavior for both soils, i.e. both tend to decrease as the water content increases, again featuring the water as a lubricant when exceeding certain values. It turns out that, within the same range of water content present in the soil of 0.13 to $0.10 \mathrm{~kg} \cdot \mathrm{kg}^{-1}$, the variation of soil friction-material of the tool turns out to be small, although they show a little more pronounced for the Planossolo. Also the soil friction angle-material, presents similar behavior for the two soils, i.e. both tend to decrease as the increase of water content in the soil, again featuring the character water lubricant when exceeding certain values. It turns out that, within the same range of water content present in the soil of 0.13 to $0.10 \mathrm{~kg} \mathrm{~kg}^{-1}$, the variation of soil friction-material of the tool turns out to be small, although a little more pronounced for Albaqualf.

Soil-material adhesion falls sharply when soil water goes from $0.11 \mathrm{~kg} . \mathrm{kg}^{-1}$ to $0.09 \mathrm{~kg}_{\mathrm{kg}} \mathrm{kg}^{-1}$ (table 5). This probably is due to the change of the state of soil moisture, i.e. in the range of $0.11 \mathrm{~kg} \cdot \mathrm{kg}^{-1}$ the soil is still friable. When the water level is around $0.09 \mathrm{~kg}_{\mathrm{kg}} \mathrm{kg}^{-1}$, the soil is very close to dry. Therefore, the observation of a sharp reduction in soil-material adhesion is in line with those of Ashburner and Sims (1984).

Pre-compression stress values for the Albaqualf related to soil water content are set out in Table 6.

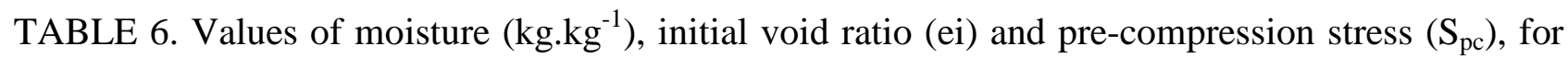
Albaqualf (mean of three repetitions).

\begin{tabular}{lll}
\hline Water content $\left(\mathrm{kg} . k g^{-1}\right)$ & ei & $\mathrm{S}_{\mathrm{pc}}(\mathrm{kPa})$ \\
\hline 0.19 & 0.37 & 78 \\
0.14 & 0.35 & 96 \\
0.12 & 0.81 & 103 \\
0.09 & 0.43 & 110 \\
\hline
\end{tabular}

Through these results the tendency of Albaqualf to increase its resistance to the normal stress applied to the soil is observed, as there is decrease in water content. The equation of the line that defines the behavior of pre-compression stress as a function of water in the Albaqualf is shown below: 


$$
\mathrm{S}_{\mathrm{pc}}=-336.49 \theta+141.02, \mathrm{r}^{2}=0.9895
$$

Table 7 shows the trend of Paleudult, in line with Albaqualf behavior, to increase its resistance to stress, as water in soil decreases.

TABLE 7. Values of the levels of moisture $\left(\mathrm{kg}_{\mathrm{kg}} \mathrm{kg}^{-1}\right.$ ), initial void ratio (ei) and pre-compression stress $\left(\mathrm{S}_{\mathrm{pc}}\right)$, for Paleudult (average of three repetitions).

\begin{tabular}{lll}
\hline Water content $\left(\mathrm{kg}_{\mathrm{kg}} \mathrm{k}^{-1}\right)$ & ei & $\mathrm{S}_{\mathrm{pc}}(\mathrm{kPa})$ \\
\hline 0.17 & 0.50 & 52 \\
0.12 & 0.49 & 100 \\
0.09 & 0.77 & 107 \\
0.08 & 0.52 & 108 \\
\hline
\end{tabular}

The behavior of pre-compression stress as a function of the water content in the soil for paleudult is defined by the equation:

$$
\mathrm{S}_{\mathrm{pc}}=-8416.2 \theta^{2}+1489.6 \theta+42.061, \mathrm{r}^{2}=0.9993
$$

The establishment of the equations that define the behavior of the pre-compression stress as a function of water in soil is important when predicting the behavior of both soils, with regards to the resistance that they offer to the pressure exerted by agricultural machinery.

By analyzing Tables 6 and 7 it may be noted that when both soils are virtually dry, with water content around $0.09 \mathrm{~kg} . \mathrm{kg}^{-1}$, pre-compression stress reaches its highest level, being the value obtained for the Albaqualf a little higher than that recorded for the Paleudult. DIAS JÚNIOR \& PIERCE (1996), MACHADO \& TREIN (2000) and SILVA et al. (2007) also showed that the soil has more resistance when it is drier.

When the water in the soil reaches $0.12 \mathrm{~kg}_{\mathrm{kg}} \mathrm{kg}^{-1}$ threshold, which defines its friable state, precompression stresses for both soils are close, But Albaqualf's is slightly higher than Paleudult's. When both soils are with the water content which gives them plastic consistency, its behavior becomes different. Albaqualf has higher pre-compression stress values, meaning that, under these conditions, this soil resists higher loads than Paleudults before deforming irreversibly. content.

Paleudults having less resistance to external loading can be explained due to its higher clay

\section{CONCLUSIONS}

It was possible to set up equations that define the relationship between the values of the internal friction angle, cohesion, adhesion, pre-compression stress, soil-tool adhesion and friction angle and the water content in the soil, for Albaqualf and Paleudult.

For both soils there was a tendency of internal friction angle, cohesion and pre-compression stress increase while water in soil decreases.

Soil tool cohesion and friction angle tended to decrease with the increase of water content in the soil, for both soils.

When friable, both soils show similar values of pre-compression stress.

In the range of soil water content that define plastic soil, Paleudults show the lower resistance to load appliance. 


\section{REFERENCES}

ABNT. Associação Brasileira de Normas Técnicas. MB - 3336 - Solo - Ensaio de Adensamento Unidimensional, Rio de Janeiro. 1990. 15p.

CAMACHO-TAMOYO, J. H.; RODRÍGUEZ, B. G. A. Evaluación de implementos de labranza a diferentes velocidades de operación y contenidos de agua del suelo. Agicultura Técnica. Chillán, v.67, n.1, p.60 - 67. 2007.

CAVALIERE, K. M. V.; ARVIDSSON, J.; SILVA, A. P. Determination of pre-compression stress from uniaxial compression tests. Soil \&Tillage Research, Amsterdam, v.98, p. 17-26. 2008.

DIAS JUNIOR, M. de S.; PIERCE, F. J. O processo de compactação do solo e sua modelagem. Revista Brasileira de Ciência do Solo, Viçosa-MG, n. 20, p.175-182. 1996.

GODWIN, R.J.; O’DOGHERTY M. J. Integrated soil tillage forces prediction models. Journal of.Terramechanics, Amsterdam, v. 44, p.3-14. 2007.

KARMAKAR, S.; KUSHWAHA L. R. Dynamic modeling of soil-tool interaction: an overview from a fluid flow perspective. Journal of Terramechanics, Amsterdam, v. 43, p.411-425. 2006.

LAMANDÉ, M.; SCHJONNING, P. Transmission of vertical stress in a real soil profile. Part I: Site description, evaluation of Shone model, and the effect of top soil tillage. Soil \& Tillage Research, Amsterdam, v. 114, p.57-70.2011a.

LAMANDÉ, M.; SCHJONNING, P. Transmission of vertical stress in a real soil profile. Part II: Efect of tyre size, inflation pressure and wheel load. Soil \& Tillage Research, Amsterdam, v. 114, p.71-77.2011b.

LAMANDÉ, M.; SCHJONNING, P. Transmission of vertical stress in a real soil profile. Part III: Efect of soil water content. Soil \& Tillage Research, Amsterdam, v. 114, p.78-85.2011c.

MACHADO, A. L. T.; TREIN, C. R. Determinação da compressibilidade em dois tipos de solos do Rio Grande do Sul. In: REUNIÃO SUL BRASILEIRA DE CIÊNCIA DO SOLO, 3., 2000. Pelotas. CD - ROM.

MANUWA, S. J. A. Performance evaluation of tillage tines operating under different depths in a sandy clay loam soil.Soil \& Tillage Research, Amsterdam, v. 103, p.399-405.2009.

RÜCKNAGEL, J.; BRANDHUBER, R.; HOFMANN, B. Variance of mechanical pre-compression stress in graphic estimations using the Casagrande method and derived matehematical models. Soil\&TillageResearch, Amsterdan, v. 106, p.165-170, 2010.

SÁNCHEZ-GIRÓN, V. Dinámica y mecánica de suelos. Madrid : Ediciones Agrotécnicas S. L., 1996. 426p.

SILVA, R. B.; LANÇAS, K. P.; MASQUETTO, B. J. Consolidômetro: equipamento pneumáticoeletrônico para avaliação do estado de consolidação do solo. Revista Brasileira de Ciência do Solo, Viçosa, v. 31, p. 607-615. 2007. 